DE DE GRUYTER

OPEN

G

Katarzyna Durniat

Wrocław University
Journal of Intercultural Management

Vol. 6, No. 4, December 2014, pp. 215-231

DOI 10.2478/joim-2014-0047

\title{
Socio-organizational mechanisms of institutional exclusion - a challenge for multicultural organizations
}

\begin{abstract}
The article provides theoretical considerations supported by empirical results of own research on the socio-cultural determinants of mobbing/bullying at workplaces, carried out on samples of adults working in different organizations in Poland (2007/8: $N=465 ; 2010: N=260)$. Referring to the selected elements of Berger and Luckman's theory of social construction of reality (1966) as well as certain socio-organizational phenomena such as mobbing, organizational climate, and organizational culture, the author proposes a hypothesis that mobbing can be seen as a kind of socio-organizational sanction applied to culturally different and poorly-socialized employees. The results of own research show that mobbing behaviours are mostly experienced by non-conformist employees who do not support the objectives and organizational procedures and negatively evaluate various factors of organizational climate. Nevertheless, numerous research results [Durniat K., 2009, 2011, Grzesiuk L., 2008, Hoel H., Zapf D., Cooper CL, 2002, Høgh A., and Dofradottir EG, 2002, Einarsen S., Mikkelsen EG , 2003] clearly show that the incidence of mobbing entails a number of negative consequences for both individuals and entire organizations. The presented course of consideration is a voice in the scientific discussion which has a direct impact on practical management - about bullying/mobbing at work as a particular threat to multicultural organizations and a challenge for their managers.
\end{abstract}

Key words: workplace diversity, organizational culture, organizational climate, cultural diversity, mobbing, secondary socialization, culture fit.

\section{Introduction}

In the reality of the 21st-century economy, determined by the phenomenon of globalization - the functioning of individuals in multicultural teams or managing

\footnotetext{
*k.durniat@psychologia.uni.wroc.pl
} 
international companies has become an ordinary experience of employees of all organizational levels, working in various institutions and enterprises around the world. The universality of this type of experience, so characteristic of the present times, does not diminish its importance or imply that individuals and organizations are always able to cope with the challenges brought about by their multicultural staffs. Today's researchers agree on the fact that human resources management in multinational companies has become a major challenge currently faced by practitioners and theoreticians of management in the 21st century [Stor M., 2006, p. 310]. The problems of managing broad diversity, which requires high degrees of flexibility and adaptability and to promote behavior with high social responsibility [Greenberg, J., Baron RA, 2000] belong to the integral aspects of modern human resources management. The term "diversity management" is quite wide-ranging and includes both visible bio-demographic differences as well as less visible socio-cultural ones [Kandola, R., Fullerton J., 1994, p. 19, Lawthom R., 2003, pp. 418-419]. Nowadays, social diversity is considered an inseparable component of organizational life [Stor M., 2006, p. 310]. Researchers emphasize that diverse human capital brings diverse skills, abilities and knowledge into an organization - a multiplicity and uniqueness of human experience, a plurality of viewpoints, and heterogeneity of cultural patterns and models of organizational behavior. For today's organizations and their managers, such input entails both a tremendous opportunity and a great challenge. Undoubtedly, the pluralism of human capital can contribute to the creation of new, unprecedented ideas and values as well as innovative services and products, thus providing the organization with an opportunity to win a global competitive advantage. The position of strategically important innovativeness, treated as a result of wider processes of organizational learning that includes every member of the organization [Bartlett CA, Ghoshal S., 2002, p. 68] is attainable under the assumption of the high adaptability and flexibility of individuals and the entire organization [Stor M., 2006, p. 311; Schuler RS at all, 2002]. Such characteristics stand in opposition to organizational narrowness, conservatism and dogmatic attitudes. Personnel strategies in international and multicultural organizations should skillfully balance between institutionalization, associated with the priority of standard solutions, and personalization, more focused on meeting the needs and goals of socially diverse employees [Stor M., 2006, p. 317]. What is emphasized today is that the formulation of personnel strategies in international corporations must be accompanied by a predetermined philosophy of social diversity. The basic premise of this approach is the claim that talents and abilities of value for the organization are distributed evenly among the representatives of all groups: racial, ethnic, or religious; both among healthy and disabled employees, heterosexual and homosexual, men and women [Lawthom R., 2003, p. 419]. An important feature of international human resources management is the increasing importance of cultural factors in solving personnel 
problems. Currently, in most countries in Europe, Asia and America, there are regulations and guidelines for actions aimed at preventing any forms of inequality, discrimination, exclusion and mobbing at workplaces [cf. Lawthom R., 2003, p. 418; Labor Code, amended in 2004, Art. 94, S 2]. Nevertheless, the existence of appropriate laws and regulations cannot protect today's organizations and their members from experiencing discrimination and mobbing at work [cf. Durniat K., 2012b, H. Hoel, Einarsen S., 2010]. Moreover, some theoretical concepts [Berger, P., Luckmann, T., 1966] and research results [Durniat K., 2010c, 2010d] allow the thesis that the multi-culture of staff, so common in modern organizations, is a factor increasing employees' chances of experiencing various forms of social ostracism and psychological terror in the workplace. In the following sections of this article, the author will provide theoretical and empirical arguments in support of this hypothesis, anchored in the sociological theory of social construction of reality by Berger and Luckmann [Berger, P., Luckmann, T., 1966], the concept of mobbing [Leymann H, 1990; Durniat K. 2006, 2008] and of organizational climate as defined by Rosenstiel and Bögel [Rosenstiel L., Bögel R., 1992]. Then, the author will briefly present the methodology for measuring mobbing at workplaces (the validated Polish psychometric tool to measure mobbing at workplaces, called the SDM questionnaire [Durniat K., Kulczycka A., 2006; Durniat K., 2007, 2008b]), an organizational climate measurement questionnaire, and selected results of own studies concerning the socio-organizational and organizational-cultural aspects of mobbing within organizations [Durniat K. 2008, 2009, 2010a, 2010b]. The results obtained by the researcher in the studies carried out in Poland supplement the international research results carried out by the world's leading and best-known researchers of mobbing [Leymann H, 1990, 1996, Zapf D., C. Knorz, Kulla M., 1996, Vartia M. 1996].

\section{An outline of the concept of social construction of reality by Berger and Luckmann}

In one of the most significant sociological works of the previous century, two German thinkers of the 1950s - Peter L. Berger and Peter Luckmann - substantiated their own thesis that although an institutional world has no ontological status of a being independent of human activities, paradoxically it is experienced by individuals as an objective and autonomous being [P. Berger, T. Luckmann, 1966; Polish transl. 1983]. The researchers explained that people who create an institutional world, enter into a dialectical relationship with their own creation - a world that re-shapes them and returns to their consciousness as an independent and objectified being. This process takes place in two successive and independent phases: through primary socialization and secondary socialization. The former involves the socialization of an individual which takes place early in human life, through the 
recognition and internalization of social norms approved by the given environment and culture, and by determining the identity and role of the individual in the surrounding socio-cultural world. Later, in their adolescent and adult life, individuals undergo successive processes of secondary socialization, which involve the internalization of the so-called "institutional sub-worlds". This process, where individuals enter institutional worlds associated with a variety of professional roles and jobs, is based on their achieving an internal state of identification with the social and professional roles they assume and is associated with learning and adopting the standards of behavior and values appropriate for the organization. Every time an individual enters into the world of another institution implies undergoing another process of secondary socialization. Thus, secondary socialization consists in the acquisition of knowledge related to the roles derived from the division of tasks and the institution's values and norms. This requires mastering the specific institutional terminology and jargon, which creates a kind of a mental map of hidden meanings and evaluations, as well as understanding the emotional and normative shades of the institutional language. The success of secondary socialization largely depends on the scope and nature of the "socialization techniques" used by the organization to motivate people to acquire the new knowledge. An indicator of successful secondary socialization is a high degree of employees' identification with their new roles and the values endorsed by the organization. It must be remembered that the existence of an institution is dialectically dependent on the level of its individual members' identification with their creation. The stronger the internalization of institutional norms and values, the more predictable and controllable the conduct of individual members of the organization. Hence, institutions aim to maintain the strongest possible control over individuals and administer painful social sanctions against those who do not show satisfactory internalization of organizational norms. The most painful institutional sanctions are derision and exclusion. It is worth noting that ridicule, slander, and social isolation are among the most characteristic forms of mobbing at work [cf. Durniat K., 2008a, 2010a, S. Einarsen, 2000; Einarsen S., Hoel H., Zapf, D., \& Cooper CL, 2003, Leymann H., 1996; Vartia, 1996]. Thus, the use of mobbing or bullying within an organization can be seen as a kind of institutional mechanism of social control over rebellious, insufficiently socialized individuals. It can therefore be speculated that experiencing bullying and mobbing most often concerns those employees who are "culturally incompatible" or those who adversely evaluate the components of the climate and culture of their organization [cf. Durniat K., 2008b; 2010d; 2010e]. 


\section{Basic assumptions, definition and methodology of the research on mobbing at workplaces}

Based on the tradition of mobbing research in Europe, fostered mainly by Swedish scholars (Heinz Leymann's theoretical foundations and methodology of research on mobbing at workplace [Leymann H, 1990, 1996], developed by D. Zapf, C. Knorz, M. Kulla [Zapf, D., C. Knorz, Kulla M., 1996], M. Vartia [Vartia M., 1996], and most recently by S. Einersen and colleagues [Einersen S., 2000, Einarsen, S., Hoel , H., \& Notelaers, G., 2009 S. Einarsen, Hoel, H., Zapf, D., \& Cooper, CL, 2003, Einarsen, S. \& Skogstad, A., 1996) - as well as on her clinical studies in the field of mobbing, the author developed her own research model and a Polish psychometric tool to measure the phenomenon [cf. Durniat K., Kulczycka A., 2006; Durniat K., 2006, 2007, 2008b, 2010a]. Underlying the mobbing research methodology has been the author's own psychological definition of mobbing, which is in accordance with the Polish legal definition of the pathology in question [cf. Labor Code, amendment of 2004, Art. 94, \$2, as cited in: Journal of Legal Acts, 2003, No. 213, item 2081]. The researcher has assumed that "Mobbing is psychological violence, taking place between at least two participants of a social interaction, where a perpetrator (less often perpetrators) systematically and deliberately targets a victim (less often victims) with repeated verbal and behavioral assaults. Although it is mostly a subjective phenomenon, it results in an objectively observable mental destabilization of the victim, their sense of injustice and absurdity and an experience of severe psychological stress. Mobbing is a process: systematically, as the persecution escalates, the victim's self-esteem and sense of professional and social competence decreases, along with increasing the feeling of helplessness" [Durniat K., 2006, pp. 428-429; Durniat K., Kulczycka A., 2006, p. 463].

The works on the creation of the SDM questionnaire - the Polish psychometric tool to study mobbing - lasted for several years [Kulczycka, Durniat 2004, Durniat, Kulczycka 2006, Durniat 2008b]. The tool, inspired by the translation of the LIPT questionnaire by Leymann [Leymann H., 1996] and supplied with a number of new statements taken from the Polish organizational reality (exploratory research: interviews with victims of mobbing at work) has been repeatedly tested and gradually evolved. The results of various statistical analyses, especially the factor analysis carried out in 2008 [cf. Durniat K., 2008b], led to the final version of the instrument, which consists of 64 test items arranged in two basic scales, called: SDM-IDM and SDM-ODC and three subscales. The SDM-IDM basic scale forms a catalog of typical mobbing behaviors (behavioral indicators) and consists of 43 items (Cronbach's $\alpha=0.956)$. The SDM- IDM scale consists of three subscales: the scale of isolating and intimidating behaviors (19 items; Cronbach's $\alpha=0.927$ ), the scale of overtly humiliating and ridiculing behaviors (17 items; Cronbach's $\alpha=0.932$ ) and the scale of behaviors hindering professional performance (7 items; Cronbach's $\alpha=0.803$ ). 
The SDM-ODC scale (21 items) reflects the most typical feelings and reactions occurring on the part of the mobbed victims (emotional and cognitive indicators). The SDM questionnaire is provided with a manual for the test takers and an answer sheet attached directly with the questionnaire. In the Polish version of the tool, all the questions are closed-ended and an ordered 5-answer scale format is used, reflecting the frequency of behaviors (from "never" to "very often"). Mobbing is diagnosed is based on the cumulative result of the SDM-IDM scale. The auxiliary SDM-ODC scale completes the picture of harassment with its interactional indicators, in the form of a set of specific feelings, interpretations and sensations experienced by the victim. The SDM questionnaire was repeatedly used by the author and other researchers to measure mobbing in Polish organizations; however, this article will focus on the selected results of the research project conducted at the turn of the years 2007 and 2008 ( $\mathrm{N}=465)$ [Durniat K. 2008b , 2008a, 2009]. The study was carried out on a heterogeneous sample of adults working in or near the city of Wrocław. The results of the SDM questionnaire were compared with the results of the adopted organizational climate questionnaire by Rosenstiel and Bögel; also, the relationship between mobbing and the socio-organizational and cultural-organizational factors were investigated1 [Durniat K. 2009, 2010b]. The project, carried out within a broad research plan, resulted in an imposing collection of interesting results, most of which have already been described in the author's other scientific publications [Durniat 2008b, 2009, 2010a, 2010d]. In this article, the author will refer only to the results corresponding to its title theme.

\section{Organizational climate according to L. Rosenstiel and R. Bögel (1992)}

Rosenstiel and Bögel's concept of organizational climate grew out of Kurt Lewin's field theory [1951]. Kurt Lewin was one of the first scientists to account for the importance of the subjective reception of the surroundings in determining an individual's behavior. According to the assumptions of field theory, Rosenstiel and Bögel assumed that human behavior in any situational context (including the context of functioning in an organization as an employee) is the result of two main factors: the individual's personality and the environment. Researchers have argued that apart from the objective factors such as management style, technological state or remuneration system, the behavior of people at their workplace is also affected by subjective factors associated with the perception of the institution by its staff and the attitude of individuals towards social phenomena taking place in the organization. In light of this assumption, organizational behavior of members of a given institution results from the clash of the formal features and culture of the organization (expressed as its mission, objectives, functions, and management

\footnotetext{
1 Readers interested in the details of the research methodology, its assumptions, questions, hypotheses, and sample selection - the author kindly asks to refer to her previously published works.
} 
style) with the needs, competencies and values of the individuals. The nature of this relationship, specific for the given organization, is the essence of its organizational climate. Rosenstiel and Bögel [1992, p. 22] define organizational climate as "a concept referring to the characteristics of the whole internal environment of an organization as perceived and evaluated by groups of its employees." The following six dimensions, considered by the researchers as essential for assessment of the prevailing organizational climate, form the corresponding 6 subscales of the questionnaire: the relationship between employees, the management style of the superiors, work organization, information and communication, representation of employees' interests, professional development and promotion opportunities (motivation). The contents of the subscales have been described in detail in other studies published earlier, which the author would like those interested to refer to [Durniat K., 2010b, pp. 139-141; 2012b, pp. 155-159]. The first translation of the tool into Polish and the validation studies on samples of Polish employees were carried out by Augustynowicz [Augustynowicz P., 1997]. Further research and cultural adaptation of the tools was done in 2006 by the author of this article [cf. Durniat, 2012b]. The researcher conducted a reliability analysis and factor analysis of the whole tool as well as the individual subscales of the questionnaire; as a result, the tool became more concise and economical and still more reliable than the first translated version of the questionnaire (with the reliability of the subscales measured by Cronbach's $\alpha$ ranging from 0.81 to 0.92) [Durniat K., 2010b; 2012b, pp. 160-163].

\section{The relationship between mobbing and organizational climate and its factors}

Based on the distribution of the SDM questionnaire results and on the descriptive statistics, the surveyed people were divided into three groups: the low-result, average-result, and high-result groups. It was assumed that mobbing concerned the people with the high results (the upper quartile). Correlation analyses were performed, comparing the results of the extreme groups in terms of mobbing with the results of the organizational climate questionnaire. The obtained results indicate fairly strong, statistically significant negative correlations between organizational climate factors and the occurrence of mobbing. The analyzed correlations are shown in Table 1.

The results indicate the existence of particularly strong relationships between mobbing and the management style of superiors. A style of management focused more on the execution of professional tasks than on employees coexists with the employees' experience of mobbing at work, while an employee-oriented management style seems to act as a buffer against the occurrence of mobbing. 
Table 1: Correlations between mobbing (and its factors) and organizational climate (and its factors) sorted in a descending order.

\begin{tabular}{|c|c|c|c|c|c|}
\hline & $\begin{array}{c}\text { SDM - } \\
\text { IDM } \\
\text { Overall } \\
\text { result }\end{array}$ & $\begin{array}{c}\text { SDM - N } \\
\text { Humiliating } \\
\text { and ridicul- } \\
\text { ing activities }\end{array}$ & $\begin{array}{c}\text { SDM - Z } \\
\text { Activities } \\
\text { hindering } \\
\text { professional } \\
\text { performance }\end{array}$ & $\begin{array}{c}\text { SDM - C } \\
\text { Isolating and } \\
\text { intimidating } \\
\text { activities }\end{array}$ \\
\hline \multicolumn{2}{|c|}{ The relationship between mobbing and organizational climate factors } \\
\hline $\begin{array}{c}\text { Organizational climate acc. to } \\
\text { Rosenstiel and Bögel: general } \\
\text { result }\end{array}$ & -0.699 & -0.679 & -0.665 & -0.693 \\
\hline $\begin{array}{c}\text { Scale P - Questions regarding } \\
\text { superiors }\end{array}$ & -0.660 & -0.648 & -0.721 & -0.654 \\
\hline $\begin{array}{c}\text { Scale K - Questions regarding } \\
\text { information and communica- } \\
\text { tion }\end{array}$ & -0.645 & -0.610 & -0.713 & -0.652 \\
\hline $\begin{array}{c}\text { Scale O - Questions regarding } \\
\text { work organization }\end{array}$ & -0.644 & -0.623 & -0.675 & -0.648 \\
\hline $\begin{array}{c}\text { Scale A - Questions regarding } \\
\text { work evaluation and promo- } \\
\text { tion opportunities }\end{array}$ & -0.585 & -0.578 & -0.637 & -0.613 \\
\hline $\begin{array}{c}\text { Scale I - Questions regarding } \\
\text { representation of employees' } \\
\text { interests }\end{array}$ & -0.549 & -0.534 & -0.606 & -0.540 \\
\hline $\begin{array}{c}\text { Scale W - Questions about } \\
\text { workmates }\end{array}$ & -0.541 & -0.5291 & -0.565 & -0.545 \\
\hline
\end{tabular}

The analyzed correlations are significant $\mathrm{p}<.050$.

Source: Own elaboration, Katarzyna Durniat

Equally strong, negative correlations were revealed between mobbing and the perception of the efficiency and reliability of communication within a company. The experience of mobbing at work also correlated negatively with all the other organizational climate factors, such as the perception of the efficiency of work organization, the adequacy of task allocation, the perception of the adequacy of work assessment as well as rewarding and promoting employees, the perception of the adequacy of representing employees' interests and the perception of the atmosphere of trust and collaboration within teams of employees.

It can be speculated that the discovered correlations are two-sided: probably a certain organizational climate and its perception stimulates the occurrence and experience of mobbing behavior, and the experience of such behavior worsens the 
perception of certain organizational climate factors. Other researchers of the phenomenon of mobbing received very similar results, confirming an association between mobbing/bullying and intra-organizational factors [Einarsen S., 2000; Einarsen S., Hoel, H., Zapf, D., \& Cooper, CL, 2003; Vartia M., 1996].

\section{Acceptance of organizational culture versus mobbing experience}

In order to verify the hypothesis of an existing relationship between greater exposure to social ostracism and mobbing at work and the cultural mismatch of employees within an organization, employees' attitude towards the organization's objectives and customary procedures was also examined. For this purpose, two very short 3-item scales were created, with the items arranged in ascending order and reflecting the intensity of the explored dimension. The participants were asked to indicate the statements best describing their attitude towards the given cultural fit dimension. The participants' declaration of awareness of general objectives set by the organization as well as their connection with more particular objectives was considered the most important indicator of personal acceptance of organizational goals. Another important indicator was the sense of coherence of the operation of teams of workers in the execution of their tasks. The surveyed people were asked about the level of understanding and support for the objectives set by the organization, sense of community and meaningfulness related to the achievement of the organization's targets, and the sense of pride in the fact of belonging to the organization. The participants' declaration of understanding, support and satisfaction with organizational projects, procedures and customs was considered as the indicator of personal acceptance of organizational ways. It was assumed that this acceptance manifests itself as employees' voluntary and satisfying participation in formal and informal meetings and events. Then a correlation analysis was carried out comparing the results obtained from the SDM questionnaire and its subscales (experience of mobbing and its specific forms) with the results showing the degree of awareness and acceptance of organizational goals and procedures. A fairly strong correlation was found between the variables. The results of the correlation analyzes are presented in the table below.

Additionally, the Mann-Whitney test was used to check whether those who do not experience any mobbing behaviors (Group 0: people with a low result in the SDM questionnaire) differ from those who do experience mobbing at work (Group 1: people with a high result in the SDM questionnaire) in their attitudes towards organizational goals and procedures. 
Table 2. Correlations between mobbing (and its factors) and factors of organizational culture

\begin{tabular}{|c|c|c|c|c|}
\hline & $\begin{array}{c}\text { SDM - } \\
\text { IDM } \\
\text { Overall re- } \\
\text { sult }\end{array}$ & $\begin{array}{c}\text { SDM - N } \\
\text { Humiliating } \\
\text { and ridiculing } \\
\text { activities }\end{array}$ & $\begin{array}{c}\text { SDM - Z } \\
\text { Activities } \\
\text { hindering } \\
\text { professional } \\
\text { performance }\end{array}$ & $\begin{array}{c}\text { SDM - C } \\
\text { Isolating and } \\
\text { intimidating } \\
\text { activities }\end{array}$ \\
Dependent variables & 0.489 & $\mathbf{0 . 5 2 0}$ & 0.509 & 0.489 \\
\hline \multicolumn{7}{|c|}{ The relationship between personal acceptance of organizational goals and experience of mobbing } \\
\hline $\begin{array}{c}\text { Personal attitude towards orga- } \\
\text { nizational objectives }\end{array}$ & 0.599 & 0.608 & $\mathbf{0 . 6 2 7}$ & 0.607 \\
\hline $\begin{array}{c}\text { Personal attitude towards orga- } \\
\text { nizational procedures }\end{array}$ & &
\end{tabular}

The examined correlations are significant, with $\mathrm{p}<.050$. The strongest correlations in a row are printed in bold.

Source: Own elaboration, Katarzyna Durniat

Table 3. Results of the Mann-Whitney test for SC and SP scales as compared to the mobbing questionnaire results (the SDM-IDM scale)

\begin{tabular}{|l|l|l|l|l|l|l|l|l|l|}
\hline Variable & $\begin{array}{l}\text { Rank sum } \\
\text { Group 0 }\end{array}$ & $\begin{array}{l}\text { Rank sum } \\
\text { Group 1 }\end{array}$ & U & Z & Level p & $\begin{array}{l}\text { Z } \\
\text { correct }\end{array}$ & Level p & $\begin{array}{l}\mathrm{N} \\
\text { Group 0 }\end{array}$ & $\begin{array}{l}\mathrm{N} \\
\text { Group 1 }\end{array}$ \\
\hline SC & 7514.000 & 14222.00 & 2158.000 & -7.48722 & 0.000000 & -8.4549 & 0.000000 & 103 & 105 \\
\hline SP & 6524.000 & 14797.00 & 1271.000 & -9.42794 & 0.000000 & -10.0109 & 0.000000 & 102 & 104 \\
\hline
\end{tabular}

The results are significant, with $\mathrm{p}<.000$.

Legend: SC - personal attitude towards organizational goals; SP - personal attitude towards organizational procedures.

Source: Own elaboration, Katarzyna Durniat

The detailed analysis of responses distribution in the two groups contrasted by the mobbing show (see: Figure 1) that the majority (over $80 \%$ ) of employees in the group of people who do not experience mobbing declared their support and identification with the goals of the organization they work for. The remaining percentage of people from this group declared their awareness of the goals of their organization even if they did not support these objectives. Interestingly, no one in the group of people who did not experience mobbing declared their ignorance of organizational goals. In the group of people with a high result in the mobbing questionnaire, the distribution of results was completely different. Most people in this group (over 60\%) were aware of the goals of their organization but they did not endorse these goals. Some people in this group (about 25\%) declared their personal endorsement of the organizational objectives, while others (about 14\%) stated they were totally unfamiliar with any goals of their employer organization. The nature of the surveyed employees' attitude towards the organizational goals and objectives is 
reflected by the detailed analysis of the responses in the two compared groups. The distribution of responses in the extreme groups is best illustrated by the following graphs:

Figure 1. Attitude towards organizational goals versus the occurrence of mobbing.
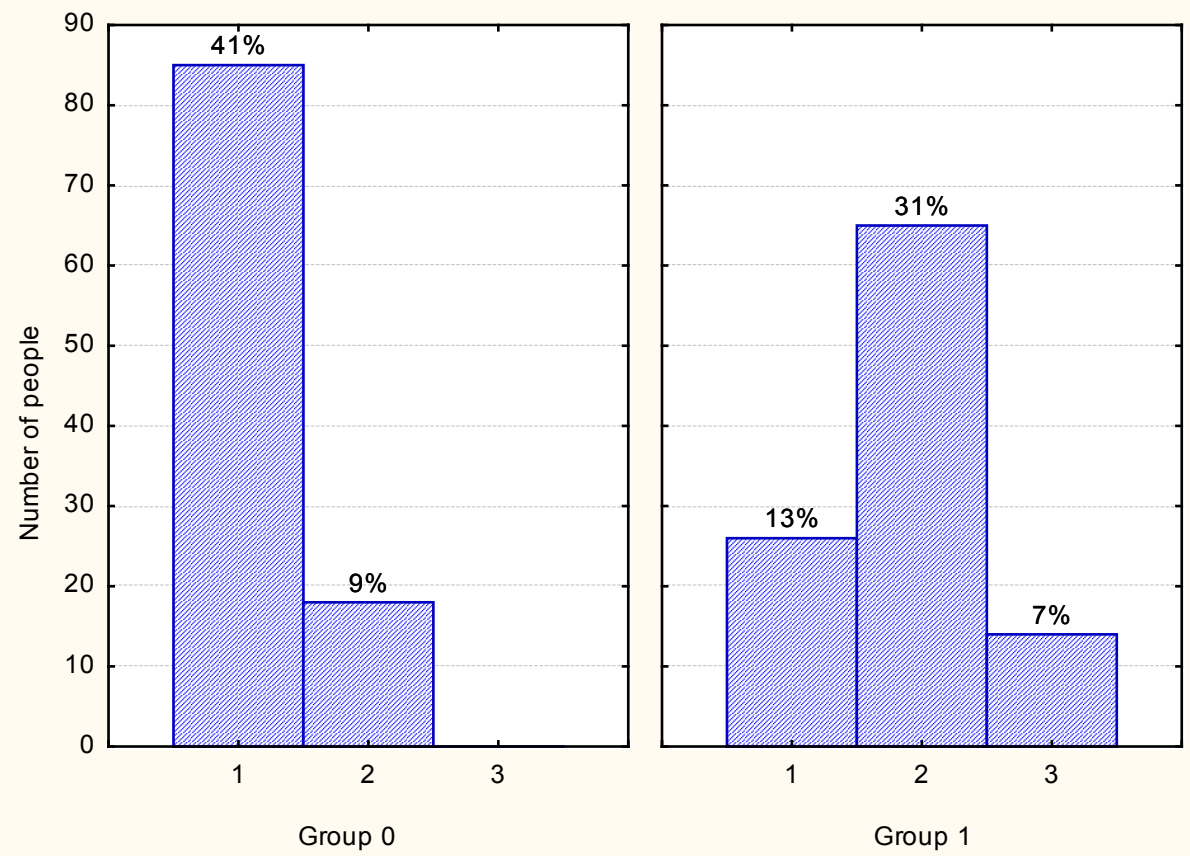

S.C.

Legend: Group 0 - people with low SDM results (no mobbing experience); Group 1 people with high SDM results (suffering from mobbing). Response categories: 1. I know the goals of my organization, I endorse and try to implement them 2 . Although I know the goals of my organization I do not endorse them3. I do not know or care about the goals my organization wants to achieve

Source: Own elaboration, Katarzyna Durniat

Assuming after G. Hofstede [2000, p. 270] that the core of organizational culture is the sense of the community of everyday routines and procedures, it was extremely important to carry out a detailed examination of this dimension and the analysis of the distribution of responses to the questions of the scale in the two groups contrasted by the mobbing result. The vast majority (around $70 \%$ ) of the group of employees who do not experience mobbing at work declared their support for the customs and routines of their employer institutions. Some people in the group (about 26\%) declared a neutral attitude toward organizational procedures, and only a few remaining people did not recognize themselves as supporters of the procedures promoted by their organizations. What is striking is that the distribution 
of responses obtained for the group of people with the high mobbing-scale results was nearly reversed: the majority (almost 60\%) of those surveyed declared their lack of interest in the procedures of their organizations, a considerable proportion of this group (almost 40\%) declared a neutral attitude towards organizational customs and procedures, while a small minority expressed a positive attitude towards the procedures promoted by the institutions that employed them. The graphical distribution of responses for the two extreme mobbing-scale result groups is shown in Figure 2 below.

Figure 2. Attitude towards organizational procedures versus the occurrence of mobbing.
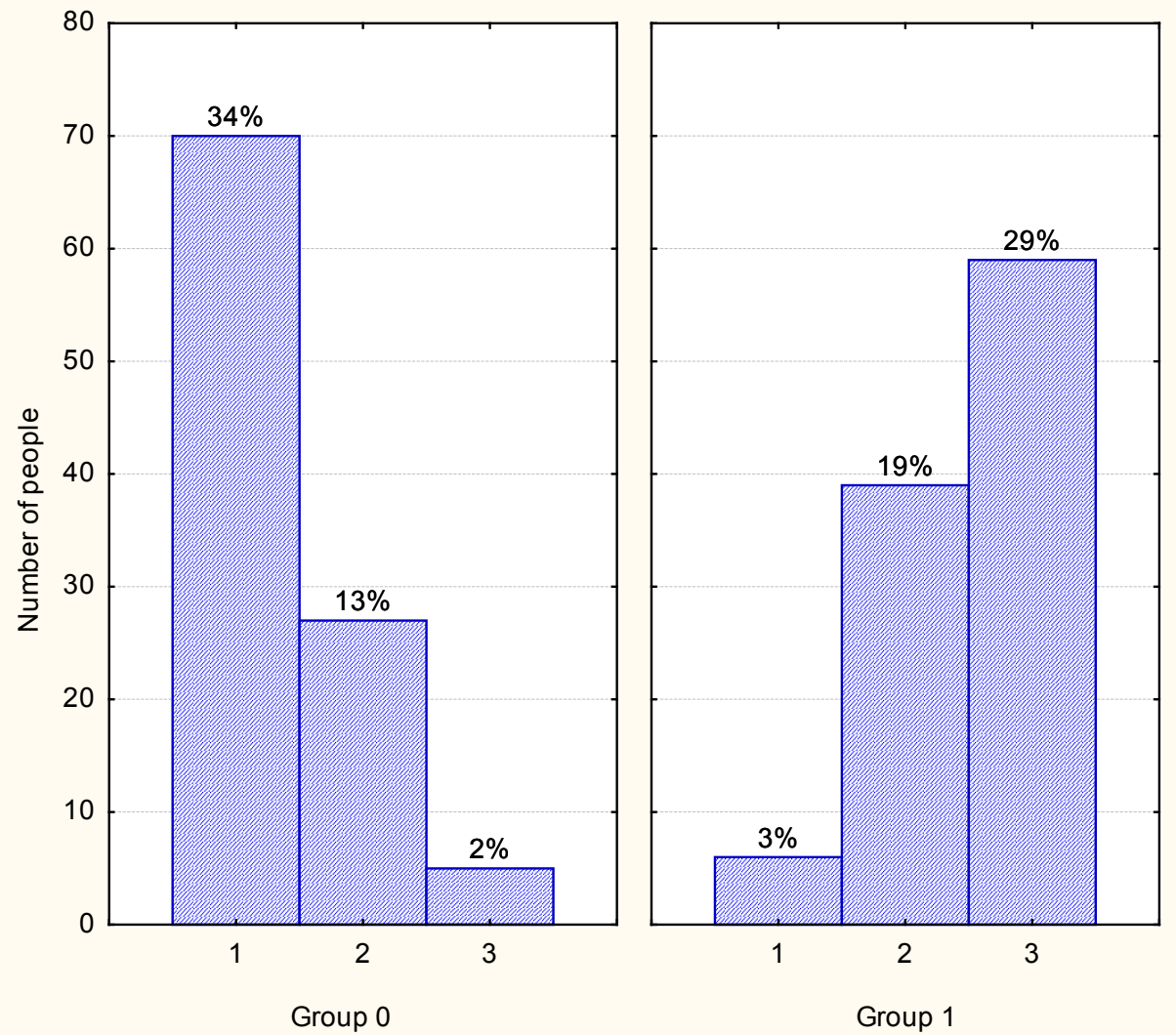

S.P.

Legend: Group 0 - people with low SDM results (no mobbing experience); Group 1 - people with high SDM results (suffering from mobbing). Response categories: 1. I like the customs and procedures of our company. I like to participate in the life of my organization. 2. I have a neutral attitude towards the customs and procedures promoted by the company I work for. 3. I dislike participating in the life of my organization and its procedures. I believe that many of the procedures should be changed.

Source: Own elaboration, Katarzyna Durniat 
It is worth adding that when asked about their subjective attribution of the reasons why they were subjected to mobbing behaviors, people who experience mobbing at work most often pointed to their own independence, tenacity, "excessive" activity and "over-involvement" as the primary causes of being mobbed. Similarly, a large group of those who only witnessed mobbing behavior looked for its sources either in excessive conciliation and lack of assertiveness on the part of the victim, or "excessive" activity and "Over-involvement" of the mobbed employees in professional life (cf. Durniat K., 2008b, 2010a, 2010b). Analogous characteristics of mobbing victims can be found in the studies conducted by the Norwegian school of mobbing researchers [Glasø, Matthiesen, Nielsen and Einarsen, 2007; Lind, Glasø, Pallesen and Einarsen, 2009]. The regression analyses conducted by the researchers indicated that high conscientiousness and low agreeableness are the traits which in a way "predispose" employees to become victims of mobbing at work.

\section{Summary}

The research findings seem to bring an important piece of knowledge on socio-cultural aspects on managing organizations (especially multicultural) and their employees. Undoubtedly, these kind of research should be continued, replicated or perhaps developed and conducted on, for example selected and comparative samples of employees coming from multi- and mono- cultural organizations. It would allow us to gain further insights into the problem described in the paper. Still, the results obtained by the author suggest that individuals who threaten the viability of the institution they work for because of their cultural oddness, poor awareness of organizational goals, negative perception of the organizational climate and unsatisfactory internalization of values, norms and patterns of behavior promoted by the organization are at particular risk of becoming mobbed at work. Among them there are often new employees, poorly socialized and having distinct cultural patterns. Both cultural strangers, who consciously reject and often also challenge institutional values, norms and patterns of behavior, and those with certain social deficits that impede their adaptation to the cultural requirements of their organization, may experience mobbing at the workplace [Durniat K., 2010b, 2010c, Grzesiuk L. Gamian-Wilk M., in press]. It should also be noted that among the group of employees subjected to mobbing there are many creative, exceptional people - ambitious and highly engaged in their work and professional tasks [Durniat K., 2010c, Durniat, 2011, Gamian-Wilk, M., 2013; Grzesiuk L., Gamian-Wilk M., in press]. Highly valuable to their organization as they should be - paradoxically - such workers are often perceived as a threat to homogeneous teams and institutions with firm cultures [Sikorski Cz., 2006]. Also employees exuding enthusiasm and original ideas tend to be perceived as a threat by their mediocre co-workers or incompetent superiors. Therefore, according to the theory by Berger and Luck- 
mann, fearing for the maintenance of its independent existence, institutions tend to use sanctions of ridicule and exclusion against rebellious and poorly-socialized individuals. However, what remains questionable is the moral side and purposefulness of such sanctions. The results of studies carried out by M. Gamian-Wilk [2013] contradict the effect assumed by mobbers (and institutions) - of increasing the submission of the victims; moreover, most of the research results clearly demonstrate the tremendous individual and organizational costs of mobbing [Durniat K., 2009, 2011, Grzesiuk L. , 2008, Hoel H., Zapf, D., Cooper CL, 2002, Høgh A., and Dofradottir EG, 2002; Høgh A., Mikkelsen E.G. and Hansen A.M., 2011, 2012; Einarsen, S., Mikkelsen E.G., 2003]. Therefore, what should definitely be supported are the demands made by modern management researchers who emphasize the need for skillful management of the growing cultural diversity through integration of multiculturalism into the system of institutional mission, values and principles. Such an attitude implies the need to develop and implement appropriate procedures to promote multiculturalism within an organization as well as a system of open, multilateral and efficient communication within an organization [Pocztowski A., 2008, p.91]. Conscious shaping of a culture of cooperation and culture of adaptation [Sikorski Cz., 2006 pp. 110-160] seems to be the most functional and ethical approach to the contemporary socio-economic conditions and challenges facing policy-makers and managers of international and multicultural organizations.

\section{Bibliography}

Augustynowicz, P. (1997) Adaptacja kulturowa kwestionariusza do badania klimatu organizacyjnego, niepublikowana praca magisterska, Wrocław: Uniwersytet Wrocławski, Instytut Psychologii.

Barlett C. A., Ghoshal S., (2002) Managing across borders. The Transnational Solution, Boston: Harvard Business School Press.

Berger, P., Luckman, T. (1983) Społeczne tworženie rzeczywistości, Warszawa: Państwowy Instytut Wydawniczy.

Durniat, K. (2006) 'Mobbing jako patologia społeczna,' in Klebaniuk, J. (ed.) Człowiek wobec masowych zjawisk społecznych, Wrocław: Oficyna Wydawnicza ATUT.

Durniat, K. and Kulczycka, A. (2006) 'Operacjonalizacja mobbingu w kontekście badań międzykulturowych’, Prace Naukowe Akademii Ekonomicznej, 1132, pp. 458 - 467.

Durniat, K. (2007) Mobbing w Polsce na tle klimatu organizacyjnego.' in. Banaszak S., Doktór, K. (ed.) Socjologiczne i psychologiczne problemy organizacji i zarzqadzania, Poznań: Wydawnictwo Wyższej Szkoły Komunikacji i Zarządzania.

Durniat, K. (2008a) 'Mobbing jako przejaw deficytów kompetencyjnych współczesnej organizacji.' in Witkowski, S. A. and T. Listwan (ed.) Kompetencje a sukces zarzqdzania organizacja. Warszawa: Difin.

Durniat, K (2008b) Społeczno-organizacyjne uwarunkowania mobbingu. niepublikowana praca 
doktorska, Wrocław: Uniwersytet Wrocławski, Wydział Nauk Historycznych i Pedagogicznych, Instytut Psychologii.

Durniat, K. (2009) 'Mobbing i jego konsekwencje jako szczególny rodzaj kryzysu zawodowego', Przedsiębiorczość $i$ zarzqdzanie, vol. 10 no. 11, pp. 129-148.

Durniat, K.(2010a) 'Mobbing as psychopathology and pathology of organization', Polish Journal of Applied Psychology, vol. 8, no. 2, pp. 41-65.

Durniat, K.(2010b) 'Mobbing jako patologiczny proces wykluczania jednostek kulturowo odmiennych', Przedsiębiorczość i zarzadzanie, vol. 11, no. 3, pp. 132-152.

Durniat, K. (2010c) 'Organizational culture's mechanism of social exclusion in the process of workplace bullying', in Panka, E. and Kwiatkowska, A. (ed.) Proceedings of the 6th European Conference on Management, Leadership and Governance, The College of Management "Edukacja" and the Professional Development Center Edukacja Wroclaw, Reading, UK : Academic Publishing Limited.

Durniat, K. (2010d) 'Prospołeczne mechanizmy zarządzania organizacją jako bufor zachowań mobbingowych', Wspótczesne zarzadzanie, no. 1, pp. 94-107.

Durniat K. (2011) 'Specyfika i konsekwencje mobbingu jako procesu obniżającego efektywność wykonania pracy zawodowej', in Juliszewski, T., Ogińska, H. and Złowodzki M (ed.), Obciqżenia psychiczne pracq - nowe wyzwania dla ergonomii, Kraków: Komitet ergonomii PAN.

Durniat K, (2012a) 'Polish adaptation of L. Rosenstiel and R. Boegel's organizational climate diagnosis questionnaire’ Polish Journal of Applied Psychology, vol. 10, no. 1, pp. 147-168.

Durniat K. (2012b) 'Prewencja i przeciwdziałanie mobbingowi w polskich organizacjach', Wspótczesne zarzqudzanie, no. 4, pp. 213- 222.

Einarsen, S. (2000) 'Harassment and bullying at work: A review of the Scandinavian approach', Aggression and Violent Behavior, vol. 5, no. 4, pp. 379-401.

Einarsen, S., Hoel, H., and Notelaers, G. (2009) 'Measuring exposure to bullying and harassment at work: Validity, factor structure and psychometric properties of the Negative Acts Questionnaire - Revised', Work and Stress, vol. 23, pp. 24-44.

Einarsen, S., Hoel, H., Zapf, D., and Cooper, C.L. (2003) 'The concept of bullying at work: The European tradition' in Einarsen, S. Hoel, H., Zapf, D., and Cooper, C.L. (ed.) Bullying and emotional abuse in the workplace: International perspectives in research and practice. New York: Taylor \& Francis.

Einarsen, S. \& Skogstad, A. (1996) 'Bullying at work: Epidemiological findings in public and private organizations', European Journal of Work and Organizational Psychology, vol. 5, no. 2, pp. 185-201.

Gamian-Wilk, M. (2013) 'Does bullying increase compliance?', Social Influence, vol. 8, no. 2-3, pp. 131-148.

Glasø, L., Matthiesen, S.B., Nielsen, M.B., and Einarsen, S. (2007) 'Do targets of workplace bullying portray a general victim personality profile?', Scandinavian Journal of Psychology, vol. 48, no. 4, pp. 313-319. 
Greenberg, J. and Baron, R.A. (2000) Behavior in Organizations. Understanding and Managing the Human Side of Work, New Jersey: Prentice Hall, Upper Saddle River.

Grzesiuk, L. i Gamian-Wilk, M. (2013) 'Mobbing w miejscu pracy. Przegląd wyników badań związanych z przejawami mobbingu, genezą i konsekwencjami’, Psychologia Spotecæna (w druku).

Hoel H. and Einarsen S. (2010) 'Shortcomings of antibullying regulations: The case of Sweeden', European Journal of Work and Organizational Psychology, vol. 19 no. 1, pp. 30-50.

Hofstede G.(1991) Cultures and Organizations: Software of the Mind, London: McGraw-Hill. cited basing on the Polish edition of the book: Hofstede G. (2000) Kultury i organizacje. Zaprogramowanie umystu, Warszawa, Polskie Wydawnictwa Ekonomiczne.

Kandola, R. and Fullerton, J.(1994) Managing the Mosaic. Diversity in Action, London: IPD.

Kulczycka, A. and Durniat, K. (2004) 'Metodologiczne problemy badania mobbingu', Prace Naukowe Akademii Ekonomicznej, 1032, pp. 640 - 650.

Lawthom R., (2003) 'Przeciw wszelkiej nierówności: zarządzanie różnorodnością', in Chmiel, N. (ed.) Psycholgia Pracy i Organizacji, Gdańsk: GWP.

Lind, K., Glasø, L., Pallesen, S. and Einarsen, S. (2009) 'Personality profiles among targets and nontargets of workplace bullying', European Psychologist, vol. 14 no. 3, pp. 231-237.

Lewin, K. (1951) Field theory in social science; selected theoretical papers, D. Cartwright (ed.), New York: Harper, Row.

Leymann H. (1990) 'Mobbing and Psychological Terror at Workplace', Violence and Victims, no. 5 , pp.119- 126 .

Leymann H. (1996) 'The content and development of mobbing at work',. European Journal of Work and Organizational Psychology, vol. 5, no. 2, pp. 165-184.

Pocztowski A. (2008) Zarzqdzanie Zasobami Ludrkimi. Strategie - procesy-metody. 2nd edition, Warszawa: PWE.

Rosenstiel L. and Boegel R. (1992) Betriebsklima geht jeden an, Bayerischen Staatsministerium fr Arbait, Familie und Sozialordnung, Monachium.

Sikorski Cz. (2006) Kultura organizacyjna, 2nd, corrected edition, Warszawa: Wydawnictwo C.H.Beck.

Stor, M. (2006) 'Międzynarodowe zarządzanie kadrami'. in Listwan, T. (ed.) Zarz̨adzanie Kadrami, Warszawa: Wydawnictwo C.H. Beck.

Ustawa z dnia 14 listopada 2003 r. o zmianie ustawy - Kodeks pracy oraz o zmianie niektórych innych ustaw. Art. 943. Driennik Ustaw, nr 213, poz. 2081 ze zm.

Schuler, R. S., Budhwar, P. and Florkowski, G. W. (2002) 'International Human Resources Management: A Research Agenda', in Arbor, A. (ed.), Handbook for International Management Research, 2nd edition, Michigan: The University of Michigan Press.

Vartia, M. (1996) 'The sources of bullying - psychological work environment and organi- 
zational climate', European Journal of Work and Organizational Psychology, vol. 5, no. 2, pp. 203-214.

Zapf D., Knorz C. and Kulla M. (1996) 'On the relationship between mobbing factors and job content, social work environment and health outcomes', European Journal of Work and Organizational Psychology, vol. 5 no. 2, pp. 215-237. 